УДК 619:615.3:614.31:637;636.087.7

(C) 2017

Бердник В. П., доктор ветеринарних наук, професор,

Бублик О. О., кандидат ветеринарних наук,

Марченко Т. М., аспірант

(науковий керівник - доктор ветеринарних наук, професор В. П. Бердник)

Щербак В. І., старший викладач

Полтавська державна аграрна академія

Трирог О. Г., керівник роботи з ветеринарного напрямку

TOB «Лабораторія натуральних технологій», м. Полтава

\title{
ФІЗІОЛОГІЧНІ ПОКАЗНИКИ КУРЧАТ-БРОЙЛЕРІВ ПІСЛЯ ВНУТРІШНЬОГО ЗАСТОСУВАННЯ МІНЕРАЛЬНОГО КОМПЛЕКСУ МG++ В УМОВАХ ГОСПОДАРСТВА
}

\section{Рецензент - доктор ветеринарних наук Б. П. Киричко}

Наведені результати випробування на 537 курчатах-бройлерах (635 контрольних) в умовах господарства препарату, виготовленого на основі розчину полтавського бішофіту. У курчат, яким давали препарат внутрішньо з водою, порівняно з контролем, була більшою середня жива маса тіла у 43-добовому вічі на 50 г, 73-добовому - на 128 г і 111-добовому на 103 г. До 43-добового віку загинуло із розрахунку від початкової загальної кількості 16 (2,9\%) курчатбройлерів у дослідній групі і 30 (4,72\%) у контрольній. На контрольних курчатах-бройлерах, порівняно із дослідними, мали економію на препараті, який не застосовували, і меншій кількості використаних кормів, але одержано значно більше збитків через нижчі прирости живої маси тіла та більшу кількість загиблих. Економічна вигода від застосування препарату лише до 43-добового віку курчат становить 5,8 гривень на вкладену 1 гривню.

Ключові слова: курчата-бройлери, біопротектор мінеральний $\mathrm{Mg}++$, розчин полтавського бімофріту (РПБ).

Постановка проблеми. Після застосування в лабораторному досліді мінерального комплексу $\mathrm{Mg}++3$ кормом і водою у курчат-бройлерів спостерігали задовільний клінічний стан та вірогідне збільшення в їх крові кількості еритроцитів і гемоглобіну. У 43-добовому віці курочки мали живу масу тіла на 303, 9 г і півники - на 271 г більшу, ніж у контролях $[1,5]$. Такі результати дають підстави випробувати препарат в умовах господарства.

Аналіз основних досліджень і публікацій, у яких започатковано розв'язання проблеми. В доступній нам літературі ми знайшли лише окремі повідомлення про результати застосування на курчатах-бройлерах РПБ і декількох препаратів, виготовлених на його основі. Їх застосували із кормом і водою в одно-двократних дозах за вмістом магнію [4]. Одержали позитивні результати $[1,5]$. Тому виникла необхідність порівняти їх із результатами випробування препаратів у напіввиробничому досліді, тобто на більшій кількості поголів'я курчат-бройлерів в умовах господарства.

Мета досліджень - вивчити фізіологічні показники курчат-бройлерів у разі внутрішнього застосування із водою мінерального комплексу $\mathrm{Mg}++$.

Матеріали і методи досліджень. Дослід проводили на птахофермі одного із господарств Полтавської області в період 10.02 - 23.03.2016 року (основна частина). Далі курчат забивали партіями в міру заявок торгівельних організацій. Остання партія була забита 30.05.2016 року.

Курчат у 2-добовому віці завезли із Луцької птахофабрики і розмістили в просторому приміщенні, розділеному на два станки. В одному 3 них було 537 голів (група 1), а в іншому - 635 (група 2, контроль). У приміщенні підтримувалась необхідна температура повітря за допомогою печі з дров'яним опаленням. Курчатам давали повнораціонні комбікорми: до 20-добового віку «Стартер», із 21 по 33-добовий - «Гровер1», а із 34-добового і до забою - «Гровер-2» та комбікорми, які готували в господарстві. Вода курчатам поступала до автонапувалок водогонами із двох баків ємкістю по 50-70 л окремо в кожний станок.

У день розміщення на фермі курчатамбройлерам застосували внутрішньо 3 водою вітамінний препарат «Інтровіт», у 2-5-ту доби - антибіотик «Енрофлокс» (з розрахунку 0,5 мл $\times 1$ л води), у 7-10-ту доби - «Інтровіт», 3 10-ї по 12ту доби - кокцидіостатик і через три тижні 2 доби підряд знову кокцидіостатик.

Курчатам групи 1 із 5-добового віку препарат 


\section{ВЕТЕРИНАРНА МЕДИЦИНА}

давали груповим методом 3 водою за 3 цикли із 24-годинним інтервалом по 7 разів у кожному циклі та 7-добовим інтервалом між циклами, а групи 2 - лише воду. Так як курчата швидко додавали в живій масі тіла, то кожний день кожного із трьох циклів близько $10 \%$ (50-55 голів) від їх загальної кількості в групі зважували і вираховували середню живу масу тіла, а потім і живу масу тіл всіх курчат групи. Далі вираховували однодобову потребу курчат у воді, яку наливали в бак. Туди ж додавали і препарат, дозу якого для курчат всієї групи визначали за описаним методом [4]. До застосування препарату і через 22-24 години після закінчення кожного циклу у 7 курчат дослідної та контрольної груп відбирали проби крові із вени крила. Їх досліджували на кількість еритроцитів, лейкоцитів та гемоглобіну за прийнятими методами [3].

Кількість використаних курчатами окремо груп 1 і 2 кормів визначали шляхом ділення загальної кількості корму на кількість кормових діб.

Результати досліджень. За період досліду курчата були клінічно здоровими. Результати гематологічних досліджень наведені в таблиці 1.

Із даних таблиці 1 видно, що після третього циклу застосування препарату у крові курчат вірогідно підвищилась кількість еритроцитів $(\mathrm{p}<0,05)$ та гемоглобіну $(\mathrm{p}<0,01)$. Ці показники свідчать, що профілактична доза препарату вибрана вірно і вона потрапила в організми курчат.

\section{1. Результати визначення кількості еритроцитів (мм ${ }^{3} /$ млн), лейкоцитів (мм ${ }^{3} /$ мис.) $^{2}$ та гемоглобіну (2/\%) у крові курчат-бройлерів, $M+-m, n 7$}

\begin{tabular}{|c|c|c|c|c|c|c|c|c|c|}
\hline \multirow{3}{*}{ Групи } & \multicolumn{6}{|c|}{ Відбір проб крові у курчат через 22-24 години після циклів } \\
\cline { 2 - 10 } & \multicolumn{3}{|c|}{1} & \multicolumn{3}{c|}{3} \\
\cline { 2 - 10 } & еритро- & лейко- & гемо- & еритро- & лейко- \\
цити & цити & глобін & $\begin{array}{c}\text { гемо- } \\
\text { цити }\end{array}$ & $\begin{array}{c}\text { еритро- } \\
\text { цити }\end{array}$ & $\begin{array}{c}\text { лейко- } \\
\text { глобін }\end{array}$ & $\begin{array}{c}\text { гемо- } \\
\text { глобін }\end{array}$ \\
\hline \multirow{2}{*}{1} & $2,88 \pm$ & $1,90 \pm$ & $7,35 \pm$ & $2,99 \pm$ & $1,91 \pm$ & $9,27 \pm$ & $3,05 \pm$ & $1,97 \pm$ & $9,33 \pm$ \\
& 0,10 & 0,06 & 0,86 & 0,06 & 0,06 & 0,39 & $0,04^{+}$ & 0,04 & $0,25^{*}$ \\
\hline \multirow{2}{*}{$2 \kappa$} & $2,79 \pm$ & $2,88 \pm$ & $6,82 \pm$ & $2,80 \pm$ & $1,91 \pm$ & $7,71 \pm$ & $2,87 \pm$ & $1,88 \pm$ & $8,25 \pm$ \\
& 0,09 & 0,10 & 0,72 & 0,09 & 0,04 & 0,46 & 0,05 & 0,06 & 0,21 \\
\hline
\end{tabular}

Примітки: 1. Різниці в показниках крові курчат груп 1 і 2 до застосування препарату були не вірогідними $(\mathrm{p}>0,05) .2 . /^{+}-\mathrm{p}<0,05, / *-\mathrm{p}<0,01$.

\section{2. Середні живі маси тіл та збереженість курчат-бройлерів}

\begin{tabular}{|c|c|c|c|c|c|}
\hline \multirow{2}{*}{ Вік, діб } & \multicolumn{2}{|c|}{ Дослідна група - 550 голів } & \multicolumn{2}{|c|}{ Контрольна група - 635 голів } & \multirow{2}{*}{$\begin{array}{c}\text { Різниця в живій масі тіла } \\
\text { дослідного курчати, } \\
\text { порівняно з контроль- } \\
\text { ним, + г }\end{array}$} \\
\hline & $\begin{array}{c}\text { середня маса тіла } \\
1 \text { голови, г }\end{array}$ & загинуло & $\begin{array}{c}\text { середня маса тіла } \\
\text { однієї голови, г }\end{array}$ & загинуло & \\
\hline 4 & 84 & - & 83 & - & 1 \\
\hline 11 & 230 & 10 & 215 & 14 & 15 \\
\hline $12-18$ & перерва & 5 & & 6 & \\
\hline 25 & 737 & 1 & 701 & 0 & 36 \\
\hline $26-32$ & перерва & 0 & & 7 & \\
\hline 39 & 1600 & 0 & 1575 & 1 & 45 \\
\hline $40-43$ & перерва & 0 & & 0 & \\
\hline 43 & 1936 & 0 & 1886 & 2 & 50 \\
\hline 73 & 3826 & & 3698 & & 128 \\
\hline 111 & 4500 & & 4397 & & 103 \\
\hline \multicolumn{2}{|c|}{ Разом загинуло } & 16 & & 30 & \\
\hline
\end{tabular}

Примітка: Жирним шрифтом наведені дні закінчення циклів застосування препарату; першого - на 5-11-ту добу, другого - 19-25-ту і третього - 33-39-ту добу. 


\section{ВЕТЕРИНАРНА МЕДИЦИНА}

Дані таблиці 2 показують, що на 4-ту добу життя дослідні курчата, порівняно із контрольними, мали середню живу масу тіла більшу на 1 г, 11-ту (1 цикл) - 15 г, 25-ту (2-й цикл) - 36, 39-ту (3-й цикл) - 45 г, 73-тю - 128, 111-ту добу - 103 г. Із наведених даних виходить, що позитивний вплив препарату на організм курчат продовжувався ще до 2,5 місяців (час спостереження) після закінчення третього циклу. Загинуло курчат у групі $1-16(2,91 \%)$ і в групі $2-30$ $(4,72 \%)$ із загальною живою масою тіл 2870 г і 11700 г відповідно (різниця 8830 г). Причому найбільше їх загинуло в період до 18-добового віку.

Це означає, що на 605 курчатах контрольної групи у 43-добовому віці не одержали вигоди: $605 \times 0,05 \Gamma=30,25$ кг живої маси тіла курчат або 23 кг курятини х 28 гр. = 644 гр. Орієнтовна вартість м'яса курчат, які загинули в цій групі, становить 28 гр. х 6,7 кг =187,6 гр. Загальна сума не одержаної вигоди дорівнює 831,6 гр. За три цикли на одне курча витрачено препарату на суму 10,3 коп. і одержали 1,06 гр. прибутку, або на 10 коп. затрат - 96 коп. 3 урахуванням і загиблих курчат загальна сума збитків орієнтовно становить 831,6 гр : $605=1,37$ гр., або на 1 гр. затрат можна було одержати по 12,7 гр. прибутку.

Згідно 3 даними облікових документів птахоферми за 18 діб (у період із 11.03 по 28.03.2016 року) курчата групи 1 з'їли 1785 кг кормів, а групи 2 (контроль) - 2005 кг. За названий період у групі 1 було постійно 536 курчат, а в групі 2 на його початку 615 , а в кінці через загибель 605. У дослідній групі було 9649 кормових діб, а в контрольній - 10964. Звідси вирахували кількість корму спожитого в середньому за один кормовий день одним курчам групи 1 та групи 2: 1785000 г : $9649=184,99$ г та $2005000: 10964=$ 182,87 г. Різниця між ними була 2,12 г. Вартість 1 кг комбікорму становить 8,5 гр., а 2,12 г - 1,8 коп. Курчаті групи 1 за 18 діб витрачено додат- ково на комбікорми 1,8 коп. х $18=38,16$ коп. За 38 діб (період основного досліду ) це становить максимально 68,4 коп.

Це означає, що із загальної суми втрат (137 коп.) віднімаємо витрати на препарат (10 коп.) та додатковий корм за 38 діб $(68,4$ коп.) і одержимо втрачену вигоду на суму 58,6 коп. Таким чином, за кожну витрачену 1 гривню на препарат та додаткові корми за рахунок приростів живої маси тіла і збереження поголів'я буде одержано прибуток на суму 5,8 гривень.

Варто зазначити, що курчата-бройлери цього досліду в 43-добовому віці мали середню живу масу тіла в групі $1-1936$ г, а в групі $2-1886$ г. В лабораторному досліді [5] середні живі маси тіл курчат-бройлерів у групі, де застосували ідентичний препарат, складали: курочки 2936,43+77,46 г і півники $3281,25+-35,73$ г, а контроль 2632,50+-43,97 г і 3010,00+-99,87 г відповідно. Різниця між даними, одержаними в лабораторному досліді і господарському, досить суттєва i, крім інших факторів, в основному є наслідком недостатньо збалансованих раціонів годівлі курчат у господарстві.

\section{Висновки:}

1. Після застосування препарату, виготовленого на основі РПБ, внутрішньо 3 водою груповим методом у курчат-бройлерів порівняно 3 контролем, була більшою середня жива маса тіла у 43добовому віці на 50 г, 73-добовому - на 128 г і 111-добовому - на 103 г. Це свідчить про те, що препарат позитивно діє на організми курчат ще до 2,5 місяців (час спостереження) після останнього застосування на 38-й добі їх життя. Тому препарати на основі РПБ матимуть більшу ефективність під час застосування на ремонтному молодняку і дорослих курях, тобто тих, що живуть більше 2,5 місяців. До 43-добового віку загинуло із розрахунку від початкової загальної кількості 16 (2,9\%) курчат-бройлерів у дослідній групі і $30(4,72 \%)$ в контрольній.

\section{3. Результати визначення втрати економічної вигоди на курчатах 43-добового віку}

контрольноӥ групи

\begin{tabular}{|c|c|c|c|c|c|c|c|c|}
\hline \multirow{3}{*}{$\begin{array}{l}\text { Кількість } \\
\text { голів }\end{array}$} & \multicolumn{4}{|c|}{$\begin{array}{c}\text { Через менші на } 50 \text { г прирости живої маси } \\
\text { тіла }\end{array}$} & \multicolumn{4}{|c|}{ Через загибель } \\
\hline & \multirow{2}{*}{$\begin{array}{l}\text { жива маса } \\
\text { тіла, кг }\end{array}$} & \multirow{2}{*}{$\begin{array}{l}\text { курятина, } \\
\text { кг } \\
\end{array}$} & \multicolumn{2}{|c|}{ вартість, гр. } & \multirow{2}{*}{$\begin{array}{l}\text { жива маса } \\
\text { тіла, кг }\end{array}$} & \multirow{2}{*}{$\begin{array}{l}\text { курятина, } \\
\text { кг }\end{array}$} & \multicolumn{2}{|c|}{ вартість, гр. } \\
\hline & & & 1 кг & всього & & & 1 кг & всього \\
\hline 605 & 30,25 & 23 & 28 & 644 & & & & \\
\hline $14^{*}$ & & & & & 8,83 & 6,7 & 28 & 187,6 \\
\hline
\end{tabular}

Примітка: /* Різниця між кількістю загиблих у контролі та групі 1. 


\section{ВЕТЕРИНАРНА МЕДИЦИНА}

2. Курчата-бройлери, яким застосовували препарат на основі РПБ, щоденно споживали на 2,12 г кормів більше і мали, порівняно 3 контролем, вищі прирости живої маси тіла що, ймовірно, є наслідком підвищеного апетиту, інтенсивнішого травлення корму та кращого засвоєння продуктів його розкладу.

3. На контрольних курчатах-бройлерах, порівняно $з$ дослідними, мали економію на препараті, який не застосовували, і меншій кількості вико-

\section{БІБЛІОГРАФІЯ}

1. Бердник В. П., Трирог О. Г. Дія мінерального комплексу на курчат-бройлерів / В. П. Бердник, О. Г. Трирог // Наше птахівництво. - 2016. - №2 (44). - С. 63.

2. Лакин Г. Ф. Биометрия / Г. Ф. Лакин. - М. : «Высшая школа». - 298 с.

3. Левченко В. І., Влізло В. В. Ветеринарна клінічна біохімія / В. І. Левченко, В. В. Влізло. - Біла Церква, 2002. - 400 с.

4. Методичні рекомендації щодо застосування розчину полтавського бішофіту у ветеринарній ристаних кормів, але одержано значно більше збитків через нижчі прирости живої маси тіла та більшу кількість загиблих. Загальна вартість економічної вигоди застосування препарату лише до 43-добового віку курчат становить 5,8 гривень на кожну вкладену 1 гривню.

4. Одержані результати показують, що потрібно продовжити випробування препаратів на основі РПБ на різних вікових групах курей в інших птахогосподарствах і фермах.

медицині та тваринництві / [Бердник В. П. і співавт.] // Затверджені НТР Державної ветеринарної та фітосанітарної служби України 21.12.2012 року, протокол № 1. - Полтава, 2012. $-19 \mathrm{c}$.

5. Результати випробування на курчатахбройлерах препаратів, виготовлених на основі розчину полтавського бішофіту / [Бердник В. П., Бублик О. О., Бердник I. Ю., Щербак В. І., Марченко Т. М., Сугак О. В.] // Вісник ПДАА. - 2016. - №1-2. - C. 44-47. 